Institute for Research on Poverty

Discussion Paper no. 1150-97

\title{
Perceived Fairness and Compliance with Child Support Obligations
}

\author{
I-Fen Lin \\ Office of Population Research \\ Princeton University \\ E-mail: ifenlin@opr.princeton.edu
}

November 1997

A version of this paper was presented at the annual meeting of the American Sociological Association in Toronto, Ontario, Canada, August 9-13, 1997. This research was supported by a grant from the National Institute of Child Health and Human Development (HD-24571), by a grant from the Wisconsin Department of Health and Social Services (DHHS-30020), and by the Center for Demography and Ecology, which receives core support from the Center for Population Research of NICHD (HD05876). I thank Nora Cate Schaeffer, Judith A. Seltzer, Sara S. McLanahan, Charles N. Halaby, and Daniel R. Meyer for detailed comments and invaluable advice.

IRP publications (discussion papers, special reports, and the newsletter Focus) are now available on the Internet. The IRP Web site can be accessed at the following address: http://www.ssc.wisc.edu/irp/ 


\begin{abstract}
This paper examines how the perceptions of nonresident fathers about the fairness of their child support orders affect their compliance with these orders. In particular, the study asks whether routine income withholding affects compliance in the absence of perceived fairness. The analytic sample includes 392 nonresident fathers who filed for divorce between 1986 and 1988 in the state of Wisconsin. Using the reports made by these fathers along with court records as an independent measure of their subsequent compliance with child support obligations over a 24-month period, the author concludes that fathers' perceptions of fairness increase their compliance with support orders. Moreover, routine income withholding has a greater effect on compliant behavior when fathers think their child support agreements are unfair than when they think their agreements are fair.
\end{abstract}




\section{Perceived Fairness and Compliance with Child Support Obligations}

Divorce creates separate households with unequal standards of living. In the first year after divorce, mothers and their minor children, on average, experience a 27 percent decline in their standard of living, in contrast to a 10 percent rise for fathers (Duncan and Hoffman 1985; Peterson 1996). Although such economic inequality may be lessened by the nonresident fathers' fulfillment of their child support obligations (Bartfeld 1997), over half of the fathers with child support orders fail to provide the full amount of support (U.S. Bureau of the Census 1991, 1995: Table B). Noncompliance with child support orders would not be such a serious social problem as it is now if the proportion of children who depend on nonresident fathers' financial support were small enough that they could be adequately supported by government welfare programs, such as Aid to Families with Dependent Children (AFDC). However, a persistent high divorce rate (U.S. Bureau of the Census 1996: Table 146) and an increasing number of nonmarital births (Ventura, Martin, Curtin, and Mathews 1997: 7, Table B) has resulted in a substantial proportion of American children living in families relying on AFDC (U.S. House Committee on Ways and Means 1996: Table 8-27). Moreover, welfare payments are rarely high enough to lift these children out of poverty (Danziger and Weinberg 1994). Because of an increasing number of children at risk of living in poverty, the failure of nonresident fathers to comply fully with their child support obligations has come to the public's attention in the current debate over welfare reform in the United States (Wiseman 1996).

Various studies have reported that nonresident fathers who fail to pay support are usually able to afford the payments (Chambers 1979; Weitzman 1985; Garfinkel and Oellerich 1989; Sorensen 1995). In response to these reports, the U.S. government has adopted rigorous methods for locating nonresident fathers and collecting their support payments (Garfinkel, McLanahan, and Robins 1994). Meanwhile, fathers' rights groups claim that most fathers fail to pay support because they have been unfairly treated

by the U.S. child support system (e.g., Burmeister 1991). According to them, if child support orders were 
fair, fathers would pay more. The extent to which this claim is valid has rarely been explored by previous researchers. This failure is due to the fact that most surveys provide no information about nonresident fathers' perceptions of the fairness of their child support orders and no independent measure of these fathers' subsequent compliance to the orders. This paper takes advantage of unique data collected in the state of Wisconsin to examine under what conditions nonresident fathers' perceptions of the fairness of their child support orders affect their compliance.

The first section reviews three approaches-the deterrence-based approach, the compliancebased approach, and the consensus-based approach — that have been used to ensure public compliance and their applications to the U.S. child support system. The second section discusses two competing hypotheses-one suggesting that routine income withholding (compliance-based approach) and perceptions of fairness (consensus-based approach) both have their particular effects on compliance, and the other suggesting that routine income withholding has a greater effect on compliance when fathers perceive their child support orders as unfair than when they think the orders are fair. The third section describes the data used for the study. The fourth section summarizes the measurements used for the analysis. The fifth section presents the empirical results. The final section summarizes the findings and discusses the implications of the results for child support policy.

\section{THREE APPROACHES FOR ENSURING COMPLIANCE AND THEIR APPLICATIONS TO THE U.S. CHILD SUPPORT SYSTEM}

In general, legal authorities have adopted three approaches to ensure public compliance with laws of any sort: the deterrence-based approach, the compliance-based approach, and the consensusbased approach. The nature of these approaches and how each approach is applied to generate compliance with child support laws are discussed below. 


\section{Deterrence-Based Approach}

The deterrence-based approach focuses on identifying actual offenders, processing civil or criminal charges, and using legal punishment to prevent these offenders from breaking the law in the future and to act as an example to deter potential offenders from breaking the law (Gibbs 1975). There are two types of deterrence. One is "specific deterrence" in which the main goal is to prevent individuals from breaking the law again by punishing their lawbreaking behavior. Examples of specific deterrence include fining actual offenders for causing traffic accidents or imprisoning actual offenders for committing fraud. The second type is "general deterrence" in which persons who commit crimes are punished to prevent other people from committing the same crimes (Gibbs 1975). An example of general deterrence occurs when individuals who are aware that their friends have been jailed for stealing learn to avoid the same punishment by not stealing. Based on this reasoning, individuals would comply with the law either because they have been punished or because they fear being punished. Researchers have predicted that both the direct and indirect experiences of being punished will increase compliance with the law, but that experiences of successfully avoiding being punished will decrease compliance with the law (Stafford and Warr 1993).

\section{Compliance-Based Approach}

Unlike the deterrence-based approach in which punishments are used to deter violators from breaking the law in the future, the compliance-based approach establishes standards and uses enforcement methods to monitor individuals' compliant behaviors before they break the law (Reiss 1984). Because compliance-based strategies tend to be used before violations occur, this approach is a proactive form of social control (Reiss 1984). There are two types of strategies under this approach. One is "randomly checking potential offenders," such as monitoring for speeding violations, checking drivers' blood alcohol levels, and testing athletes for drug use. The other type is "checking every potential 
offender," as with income tax withholding, in which a proportion of earned income is automatically withheld to ensure that everyone complies with his or her tax obligation.

\section{Consensus-Based Approach}

The consensus-based approach refers to the situation in which individuals comply with a law not because they fear the punishment but because their personal norms coincide with the norms defined by the law (Horwitz 1990). The congruence of individual motivation and social norms can be initiated in two ways. One is to pass new laws that are consistent with individuals' attitudes. For example, the recent change in attitude of the majority of U.S. citizens toward welfare dependency motivated federal welfare reform. The other type of strategy is to change individuals' attitudes by the enactment of new laws. For example, after the U.S. Civil War, new laws prohibited race-based discrimination.

\section{Applications of the Three Approaches to Child Support Compliance}

The U.S. child support system has used a combination of deterrence-based, compliance-based, and consensus-based approaches to ensure nonresident fathers' compliance with their child support obligations.

Deterrence-based methods include jailing noncompliant fathers and intercepting noncompliant fathers' federal and state tax refunds. In criminal cases, making actual offenders pay fines or confining them in prisons are methods to punish those who harm others. In the child support setting, the "crime" is not the act of harming others but failure to take actions to help the other parent raise their children. The "punishments" are given when noncompliant fathers fail to pay a substantial amount of support and are caught by child support enforcement agencies (Chambers 1979; Lempert 1981-1982). 
Compliance-based strategies include automatically withholding child support payments from the paychecks of nonresident fathers. This strategy is used to collect child support that is currently due, and it is implemented before fathers miss any child support payments. ${ }^{1}$

Consensus-based approaches include encouraging divorcing parents to use mediation services, rather than the courts, to reach mutually acceptable child support agreements (Pearson and Thoennes 1985), or setting equitable child support guidelines and legal procedures for determining a fair child support order.

Among these three approaches coexisting in the U.S. child support system, the compliance-based approach—automatically withholding child support from employed fathers' paychecks—has been shown to be an effective method to collect support. Using Wisconsin as a case study, Meyer and Bartfeld (1992) found that routine income withholding increases the child support pay-to-owe ratio (the ratio of months paid to months owed), the probability of making any payment, and the probability of paying 95 percent or more of what is due. Furthermore, using a national data set, Garfinkel and Robins (1994) found that even the presence of the routine income withholding requirement in courts, not necessarily the actual implementation of such a requirement, increases child support collection rates for those parents with support orders. Although no national studies have been conducted to evaluate the effect of the actual implementation of routine income withholding on child support compliance, Garfinkel and Klawitter (1990), using data from Wisconsin, estimated that the effect of routine income withholding varies from an 11 percent improvement to a 28 percent improvement.

Although routine income withholding has been shown to be an effective strategy for collecting support, it is not a panacea for the noncompliance problem for two reasons. First, although the 1988 Family Support Act requires routine income withholding to be applied presumptively to cases enrolled in

\footnotetext{
${ }^{1}$ Income withholding due to delinquency, a less rigorous strategy than automatic income withholding, is a mixture of deterrence-based and compliance-based approaches because the enforcement will not be implemented until nonresident fathers have missed their child support payments by more than 30 days.
} 
the Child Support Enforcement program, many states failed to implement the requirement because of a lack of administrative capacity (Garfinkel, McLanahan, Seltzer, and Meyer 1997: 17). Second, routine income withholding is difficult to implement for those nonresident parents who are unemployed or selfemployed, and it is also difficult to keep track of employment changes for those parents who do not have stable jobs. $^{2}$

The difficulty of implementing income withholding has been summarized by Gordon (1994: 73), who used data from the Office of Child Support Enforcement to estimate that the median time between the first and second withholding period is 10 months for AFDC cases and 8 months for non-AFDC cases. These gaps may reflect the period of nonresident parents' unemployment, the time taken by child support enforcement agencies to re-issue withholding orders, or both. Because of the difficulty of tracking employment changes by nonresident fathers after the initial support orders, Meyer and Bartfeld (1992:

14) found that withholding income had a decreasing effect on the child support pay-to-owe ratio over 3 years in Wisconsin.

Policymakers may adopt one of two approaches to overcome the barriers to implementing routine income withholding: first, strengthening the use of routine income withholding, or second, adopting consensus-based strategies to enhance the fairness of child support orders so that fathers will voluntarily comply with their support orders, as fathers' rights groups have claimed. However, recent welfare reform has put more emphasis on the first approach than on the second. For instance, the 1996 Personal Responsibility and Work Opportunity Reconciliation Act requires all states to actually carry out mandatory income withholding (Public Law No. 104-193, 1996: 2213). This law also requires employers

\footnotetext{
${ }^{2}$ Note that the social security and income tax systems also encounter the difficulty of tracking the earnings of people who are self-employed or have irregular jobs. However, the tax system seems to be doing a better job than the child support system. This may be the case partly because income tax is under a standardized, widespread administration while routine income withholding for child support is not, and partly because people know fewer other people who successfully escape from income tax obligations than those who escape from child support obligations.
} 
to report the names, addresses, and social security numbers of their newly hired employees to the Directory of New Hires for monitoring changes of nonresident fathers' employment (Public Law No. 104-193, 1996: 2210). Consensus-based strategies that enhance nonresident fathers' voluntary compliance with their child support obligations are not being given enough attention by policymakers and researchers. ${ }^{3}$

The perceptions of fairness held by nonresident fathers are an important policy issue because routine income withholding is still not as widely implemented in most states as in Wisconsin, and it will take some time for the implementation to occur after the current reform. If perceptions of fairness could guide nonresident fathers' compliant behavior, it would be important to enhance the fairness of the child support guidelines and legal procedures to set support orders that are considered "fair."

Although little is known about whether nonresident fathers would have complied with their child support obligations if they considered their child support orders to be fair, previous researchers (e.g., Beller and Graham 1991; Teachman 1991; Argys 1993) have shown that nonresident fathers are likely to comply when they have a "voluntary" child support agreement or when their divorce was uncontested. ${ }^{4}$ Moreover, nonresident fathers in the studies of Greif (1985: 124), Nuta (1986), and Arendell (1995: 127) claimed that they did not pay a full amount of child support because they thought their support orders were unfair. The findings of these studies imply that if child support orders were thought to be fair (and fathers agreed with the amount of support), nonresident fathers would voluntarily comply with their child support obligations.

\footnotetext{
${ }^{3}$ However, the relationship between the fairness of child support arrangements and nonresident fathers' compliance has been discussed frequently among fathers' rights groups (e.g., Harrington 1996).

${ }^{4} \mathrm{~A}$ "voluntary" divorce or an uncontested divorce does not necessarily mean that parents will perceive their child support agreements as "fair." Parents may agree on a settlement that they think is likely to obtain the court's consent rather than seeking a settlement that they think is "fair" (e.g., Mnookin and Kornhauser 1979).
} 
This study examines under what conditions nonresident fathers' perceptions of the fairness of their child support orders affect their compliant behavior. ${ }^{5}$ In particular, the study asks whether routine income withholding has a greater effect on compliance when fathers perceive their child support orders as unfair than when they think the orders are fair. Two competing hypotheses can be derived from the literature of social control. The first suggests that the external enforcement has a greater effect on individuals' law-compliant behavior when they do not internalize moral values than when they do. This can be called the "interaction hypothesis." The second hypothesis suggests that individuals' internal evaluations and external enforcement both have their particular effect on law-compliant behavior. This hypothesis can be called the "independence hypothesis." How these two hypotheses are related to the child support situation is discussed in the next section.

\section{INTERACTION VERSUS INDEPENDENCE HYPOTHESES}

In the literature of social control, researchers have proposed and tested the interaction hypothesis and the independence hypothesis to examine the effect of the threat of sanction (external enforcement) and of moral commitment (internal evaluation) on individuals' involvement in illegal behavior. The rationale and empirical evidence for each of these two hypotheses are summarized below.

\section{Interaction Hypothesis}

Previous researchers (e.g., Thibaut and Kelley 1959; Toby 1964: 333; Andenaes 1971: 956; Zimring 1971: 41; Gibbs 1975: 80; Tittle 1977: 592) have suggested that perceptions of the threat of

\footnotetext{
${ }^{5} \mathrm{~A}$ study of the same data set shows that nonresident fathers are more likely to think their child support orders are "unfair" when they have a greater amount of income, when their child support orders are decided using the Wisconsin child support guideline, and when their child support orders are higher (Lin, 1997). None of the following factors affect nonresident fathers' perceptions of the fairness of their child support orders: mothers' income, whether or not mothers are AFDC recipients, whether parents remarry or are cohabiting, number of children, and whether parents have legal representation during their divorce.
} 
legal sanctions influence the extent of involvement in illegal behavior only among those individuals who have not internalized legal norms. Individuals who are morally committed to a norm will not violate it, regardless of their perceptions of the certainty and severity of legal sanctions. In other words, legal punishment is important in the social control process when individuals fail to internalize legal norms. Some empirical studies support this hypothesis; for example, Silberman (1976) found that the deterrent effect of threats of legal punishment is significantly greater when moral commitment is low. Moreover, Thibaut, Friedland, and Walker (1974: 798) showed that when subjects perceived their tax amount as fair, auditing tax payments did not significantly increase compliance, but when subjects perceived their taxes as unfair, auditing did significantly increase compliance.

\section{Independence Hypothesis}

Blake and Davis (1964) criticized the interaction hypothesis of social control because it seems to imply that individuals who have internalized a norm will not violate it even if they perceive legal punishment as unlikely or trivial. They further argued that threats of legal punishment should have a deterrent effect regardless of the level of moral commitment. They suggested that both moral commitment and perceived threats of legal sanctions should be viewed as "inhibitory variables" in the process of social control. Both are sources of resistance to committing deviant behavior, and their effect on involvement in illegal behaviors should be independent. This hypothesis also receives empirical support; for instance, Grasmick and Green $(1980,1981)$ found that the perceived threat of sanctions determined their subjects' future involvement in illegal behavior (e.g., theft, tax fraud, and drunk driving) at almost all levels of moral commitment (1980: 10).

\section{Two Competing Hypotheses Concerning Perceptions and Routine Income Withholding}

In the child support situation, routine income withholding may be analogous to legal punishment and perceptions of fairness analogous to moral commitment. Thus, the interaction hypothesis and the 
independence hypothesis discussed in the literature of social control could also be examined in the child support situation. Based on the interaction hypotheses, both perceptions of fairness and withholding will increase compliance, but routine income withholding will have a greater effect on fathers' compliance in the absence of perceived fairness. In this argument, perceptions of fairness are analogous to internalized norms. In contrast, the independence hypothesis argues that routine income withholding affects nonresident fathers' compliance with their child support orders, regardless of fathers' perceived fairness.

The remainder of this paper examines these two hypotheses. The data and sample are described in the following section. Next, three key measures-compliance ratio, perceptions of fairness, and routine income withholding — and other control variables are described. The last section presents the results of the multivariate analysis. The paper concludes with a discussion of the implication of these results for child support policy.

\section{DATA AND SAMPLE}

In this study, I examine a sample, from 20 Wisconsin counties, of divorced parents who began court proceedings between July 1, 1986, and June 30, 1988. Two data sets are used in this study. The Wisconsin Court Record Database (CRD) provides three types of information. The first is demographic information at the time parents filed for divorce: date of petition, date of marriage, county where parents filed for divorce, age of the two parents, and number and age of their children. The second is information regarding the results of court actions: date and reasons of court actions, whether child support was ordered, amount of child support ordered, parents' incomes, whether the support order was calculated as a percentage of the nonresident parent's income, whether legal representation was involved, whether parents agreed on child support (verbally or in writing) without courts deciding for them, the terms of legal and physical custody arrangements, whether a property settlement was involved, and whether routine income withholding was in effect. The last type of information in the CRD is the monthly amount 
of child support paid after court actions. Because the CRD is limited to Wisconsin, the results cannot be generalized to the U.S. population as a whole. But the study design does allow an analysis of how parents who entered the court perceive the fairness of their child support orders under the same legal environment.

The second data set is the Parent Survey 2 (PS2), which consists of a telephone interview with both nonresident and resident parents whose court cases were in the CRD. The survey was conducted by the Institute for Research on Poverty between April and October 1989, and in this study both mothers and fathers were asked about their child support agreements and payment behavior in 1988. The PS2 also asked both mothers and fathers about their perceptions of the fairness of their child support agreements. In addition, the PS2 supplements data about legal arrangements and parents' demographic characteristics available in the CRD. The PS2 includes both self and proxy reports about the other parent's marital status and income information in 1988. Of the 1,146 divorce cases (i.e., 1,146 mothers and 1,146 fathers) in the $\mathrm{CRD}$, the overall response rate to the PS2 was 62 percent. At least one parent was interviewed in 82 percent of the families. Mothers had a higher response rate (67 percent) than fathers (58 percent). Interviews were completed for both parents in 43 percent of the cases.

Difficulty in locating fathers and interviewing both the mother and the father in the same family frequently accounts for low completion rates in surveys using court cases as the sample frame. The PS2 has a higher completion rate $^{6}$ for successfully interviewing fathers and former couples than the Stanford Child Custody Project (30 percent and 21 percent in Maccoby and Mnookin 1992: 318); it has a

${ }^{6}$ The completion rate is calculated as the number of father respondents (or couple respondents) divided by the number of fathers (or families) who were in the full sample at the time the survey went into the field. The denominator includes cases that were ineligible because there had been a reconciliation; because there had been a death of either the respondent, the child, or the ex-spouse; or because the potential respondent either could not be located or refused to be interviewed. Some were not interviewed because they were non-English speaking. The completion rates for the Stanford Child Custody Project, the Survey of Absent Parents, and the California Family Court Service Snapshot Study have been re-calculated based on the above definition. Thus, the completion rates reported here are not the same as the reported response rates in those other studies. 
completion rate similar to that of the Survey of Absent Parents in Florida and Ohio (58 percent and 50 percent in Rubin, O'Brien, and Sudman 1988); but it has a lower completion rate than that of the California Family Court Service Snapshot Study (66 percent and 63 percent in Depner, Cannata, and

Ricci 1994, Appendix A). The advantage of combining information from PS2 and CRD is that it allows researchers to investigate nonresident fathers' perceived fairness and their subsequent compliance with child support obligations.

Because the most common custody arrangement at the time the PS2 was conducted was for children to be living with their mothers, this study is restricted to 900 divorce cases (i.e., 79 percent of the CRD sample) in which the mother had sole physical custody of minor children for more than 6 months (i.e., 180 days) in 1988. Of the 900 court cases meeting this criterion, 521 nonresident fathers were interviewed in the PS2. After excluding some interviews for a variety of reasons, 392 divorced nonresident fathers with an active child support order are included in the analytic sample.

\section{MEASUREMENTS}

The measurements used in this study have three advantages. First, the PS2 provides information about nonresident fathers' perceived fairness of their child support orders, which is rarely available in other large-scale surveys concerning child support. Second, nonresident fathers' compliant behavior is measured after their reported perceptions of fairness, which provides researchers with a reasonably clean measure of the causal link between attitude and behavior. Finally, because the child support system in

\footnotetext{
${ }^{7}$ One hundred twenty-nine fathers were excluded from the analysis. A number of fathers were dropped because the interviews were incomplete, a minor child or ex-spouse had died, a reconciliation had occurred, a child support order was pending, the father was not reported as a child support payer in 1988, or the father was no longer the sole child support payer after the survey. Also excluded were fathers who had child support orders less than 24 months after the survey and fathers who were interviewed but did not report their perceptions of the fairness of their child support orders. Research using the same data set has shown that excluding unlocated fathers and nonparticipating fathers does not bias the estimates of factors predicting child support payments (Lin, Schaeffer, and Seltzer, 1997).
} 
Wisconsin effectively enforces the requirement that child support be paid through the Clerk of the Court, the amounts of child support orders and payments obtained from the CRD are unlikely to be biased by fathers' self-reporting (Schaeffer, Seltzer, and Klawitter 1991). Three key variables-compliance ratio, perceptions of fairness, and routine income withholding — as well as other control variables are summarized below.

Compliance Ratio

Child support compliance is measured as a ratio of the total amount of child support paid to the total amount of child support owed for 24 months following the month when the PS2 was conducted. For example, if a father was interviewed on any day in April 1989, his child support orders and payments between May 1, 1989, and April 30, 1991, were used to compute the compliance ratio. The starting date of child support orders, rather than the date of court hearing, is used to compute child support compliance. This procedure captures child support that is ordered retroactively. The compliance ratio ranges from 0 to 2.48, as shown in Table 1 . In this sample, about 5 percent of the fathers owed child support but did not pay any; 33 percent paid less than what they owed; 42 percent paid about the actual amount they owed (95 percent to 105 percent); and 20 percent paid more than what they owed.

The compliance ratio in this study is much higher than the statistic obtained from national data. For example, the Current Population Survey shows that among nonresident mothers who were supposed to receive child support in 1991, about 25 percent received nothing, another 25 percent received partial payments, and 50 percent received full payment (U.S. Bureau of the Census, 1995: Table B). Compared with national statistics, the sample included in the study tends to underrepresent fathers who do not pay any support.

Four possible factors may contribute to high compliance ratios. First, the sample examined in this study includes recently divorced fathers. The average length of separation at the time of interview is about 2 years. Child support compliance is likely to be higher just after separation or divorce, and higher 
TABLE 1

Distribution of Child Support Compliance Ratio for a 24-Month Period

Compliance Ratio in Percentage

Number of Cases (Percentage)

\begin{tabular}{|c|c|}
\hline $0 \%$ & $(4.59 \%)$ \\
\hline $.01-10 \%$ & $(1.53 \%)$ \\
\hline $10.01-20 \%$ & $(1.28 \%)$ \\
\hline $20.01-30 \%$ & $(1.02 \%)$ \\
\hline $30.01-40 \%$ & $(2.04 \%)$ \\
\hline $40.01-50 \%$ & $(1.79 \%)$ \\
\hline $50.01-60 \%$ & $(3.57 \%)$ \\
\hline $60.01-70 \%$ & $(3.57 \%)$ \\
\hline $70.01-80 \%$ & $(5.36 \%)$ \\
\hline $80.01-90 \%$ & $(7.14 \%)$ \\
\hline $90.01-95 \%$ & $(6.12 \%)$ \\
\hline $95.01-99.99 \%$ & $(17.60 \%)$ \\
\hline $100 \%$ & $(8.93 \%)$ \\
\hline $100.01-105 \%$ & $(15.82 \%)$ \\
\hline $105.01-110 \%$ & $(6.63 \%)$ \\
\hline $110.01-120 \%$ & $(6.63 \%)$ \\
\hline $120.01-130 \%$ & $(2.30 \%)$ \\
\hline $130.01-140 \%$ & $(.51 \%)$ \\
\hline $140.01-150 \%$ & $(.77 \%)$ \\
\hline $150.01-160 \%$ & $(1.28 \%)$ \\
\hline $160.01-170 \%$ & $(.51 \%)$ \\
\hline $179 \%$ & $(.26 \%)$ \\
\hline $190 \%$ & $(.26 \%)$ \\
\hline $216 \%$ & $(.26 \%)$ \\
\hline $248 \%$ & $(.26 \%)$ \\
\hline Mean $^{\mathrm{a}}$ & .89 \\
\hline Median & .99 \\
\hline S.D. & .35 \\
\hline Total N & 392 \\
\hline
\end{tabular}

Source: Wisconsin Court Record Cohorts 7 and 8, 1989-1991. The pay-to-owe ratio is computed using the total amount of child support owed and paid for 24 months after the month that the father was interviewed. If there is a percentage order, income information from Department of Revenue, Department of Industry, Labor, and Human Relations, Court Records, or fathers' report in the Parent Survey 2 (income is adjusted for inflation) is used for computation.

Notes: Percentage totals may deviate slightly from $100 \%$ due to rounding error.

${ }^{a}$ Mean, median, and standard deviation (S.D.) are calculated after the distribution is top-coded to 2. Mean, median, and S.D. equal .87, .99, and .31 respectively after the distribution is top-coded to 1.2 ; and equal $.84, .99$, and .28 respectively after the distribution is top-coded to 1 . 
among divorced parents than unmarried parents. Second, the sample included here is restricted to couples divorcing in Wisconsin. Wisconsin had the highest child support collection rates across 43 states between 1987 and 1991 (Garfinkel, Miller, McLanahan, and Hanson 1996). Third, the sample included in the analysis is a group of divorced nonresident fathers who have an active child support order, who can be located and contacted, and who are willing to participate in the survey. Past research has shown that survey participants tend to have higher amounts of child support orders and to make higher child support payments than survey nonparticipants do (Schaeffer, Seltzer, and Klawitter 1991).

The last factor that may contribute to high calculated compliance ratios is that most child support orders, during the period of the study, are based on a percentage of nonresident parents' income, and the income may be underestimated in these data. As a result, the denominator of the compliance ratio is underestimated. This may occur either because the amount of ordered child support is not adjusted to reflect the increase in nonresident fathers' incomes (thus burden is less and compliance is greater), or because the amount of ordered support increases over time due to the increase in fathers' incomes. The data do not, however, include new estimates of fathers' income information. In this analysis, if the amount of the child support order is recorded as a percentage of the father's income, income information from the Wisconsin Department of Revenue (DOR), the Department of Industry, Labor, and Human Relations (DILHR), parents' report to the court (CRD), or fathers' reports of their income in 1988 (PS2) is used to compute the amount of support owed. As reported in this study, 68 percent of the 392 fathers had a fixed amount of ordered child support, while determinations of child support were made for 30 percent of the fathers from DOR data, for 12 percent of the fathers from DILHR data, for 5 percent of fathers from CRD data, and for 6 percent of fathers from the PS2. ${ }^{8}$ These sources of income information

\footnotetext{
${ }^{8}$ The priority for extracting income information from different sources is DOR, DILHR, CRD, and then PS2. The sum of the percentages does not equal 100 percent because more than one source of information could be used to calculate the total amount of child support ordered for the same father within the 24-month period.
} 
are controlled in the model because they may be correlated with other independent variables in the model that predict child support compliance.

\section{Perceptions of Fairness}

Fathers' perceptions about the fairness of their child support order are measured by one question in the PS2: "Considering your financial resources and obligations, the financial resources and obligations of the other parent, and the needs of your child(ren), how fair was the agreement you had during 1988 for (child/family) support payments? Would you say the agreement was very unfair, somewhat unfair, somewhat fair, or very fair?" Of the 392 fathers, 26 percent said their support order was "very unfair," 32 percent said "somewhat unfair," 29 percent said "somewhat fair," and 14 percent said "very fair." Fathers who answered "very unfair" and "somewhat unfair" are combined. The same is done for fathers who answered "somewhat fair" and "very fair."

\section{$\underline{\text { Routine Income Withholding }}$}

The measure of the use of routine income withholding is the number of days during the 24-month period when the withholding order was in effect. Two-thirds of the analytic sample (67 percent) had a withholding order for 2 full years (730 days), 17 percent had a withholding order for any amount of time less than 2 years, and 16 percent had zero days of withholding. To simplify the analysis so that withholding would be in effect long enough to be implemented, a cutoff point (548 days, 1.5 years) was chosen to divide samples into two groups: one group of fathers with no or limited withholding (less than 548 days) and the other group of fathers with more or complete withholding (equal to or greater than 548 days) during the 24-month period..$^{9}$

${ }^{9}$ Different cutoff points ( 0 days, 183 days, 365 days, and 730 days $)$ were tested to examine the extent to which the first-order relationship is sensitive to different points chosen (data not shown). Results indicate that the means of compliance ratio are about the same across different groupings. 
To examine to what extent fathers with more days of income withholding differ from those with fewer days of income withholding, I compared selected variables for these two groups of fathers, as shown in Table 2. The results indicate that fathers who have routine income withholding for less than 548 days are more likely to be self-employed and enter the court system earlier (i.e., longer time period between petition date and interview date) than fathers who have routine income withholding equal to or greater than 548 days. On the other hand, fathers who have routine income withholding equal to or greater than 548 days have a higher compliance ratio during the 24-month period and are more likely to have a support order expressed as a percentage of fathers' incomes than fathers who have routine income withholding less than 548 days.

The comparison shows that fathers who are self-employed are less likely to let the child support enforcement system withhold their income. Moreover, fathers who enter the Wisconsin court system earlier are less likely to have a withholding order because routine income withholding did not become presumptive until 1987 in Wisconsin, and the sample examined here entered the court system between July 1, 1986, and June 30, 1988. The relationship between the use of the percentage order and the adoption of withholding is unclear. The higher proportion of fathers with a percentage order in the group of fathers with more days of withholding may occur because the presumptive use of the percentage guideline and routine income withholding were established about the same time in Wisconsin. Thus, the relationship between the use of percentage order and the adoption of income withholding may be due to a common factor-the change of the child support laws in Wisconsin. Finally, the use of routine income withholding increases fathers' compliance during the 24-month period.

\section{Relationship among Compliance Ratio, Perceptions of Fairness, and Withholding}

To examine the relationship among the three key variables used in the study, I compare the proportion of fathers in five ranges of compliance ratio by their perceptions of fairness and use of routine income withholding. The results are shown in Figure 1. The five ranges of child support compliance are: 


\section{TABLE 2}

\section{Comparison of Selected Variables for Nonresident Fathers Who Had Routine Income Withholding Less Than 548 days and Fathers Who Had Routine Income Withholding Equal to or Greater Than 548 days $(\mathrm{N}=392)$}

Variables Withholding $<548$ Days Withholding $\geq 548$ Days

Diff

Child support compliance ratio ${ }^{\mathrm{a}}$

$.74 \quad(.40)$

.91

$*$

Perceptions of fairness (1 if fair)

$.42 \quad(.50)$

.42

ns

Parents' Resources and Families' Characteristics

\begin{tabular}{|c|c|c|c|c|c|}
\hline Father's income in $1988(\ln ($ dollar+ 1)) & 9.94 & $(1.29)$ & 9.96 & $(.75)$ & ns \\
\hline Father was self-employed at final & & & & & \\
\hline judgment (1 if yes) & .24 & $(.43)$ & .05 & $(.22)$ & * \\
\hline \multicolumn{6}{|l|}{ Father remarried or was cohabiting } \\
\hline in 1988 ( 1 if yes) & .28 & $(.45)$ & .30 & $(.46)$ & $\mathrm{ns}$ \\
\hline Mother's income in $1988(\ln ($ dollar+ 1)) & 8.64 & $(2.53)$ & 8.37 & $(2.93)$ & $\mathrm{ns}$ \\
\hline \multicolumn{6}{|l|}{ Mother was on AFDC at final } \\
\hline judgment (1 if yes) & .19 & $(.40)$ & .13 & $(.34)$ & $\mathrm{ns}$ \\
\hline \multicolumn{6}{|l|}{ Mother remarried or was cohabiting } \\
\hline in 1988 ( 1 if yes $)$ & .36 & $(.48)$ & .41 & $(.49)$ & ns \\
\hline Number of minor children & 1.85 & $(.92)$ & 1.92 & $(.84)$ & ns \\
\hline Age of the youngest child (years) & 7.11 & $(3.71)$ & 6.62 & $(3.53)$ & $\mathrm{ns}$ \\
\hline \multicolumn{6}{|l|}{ Aspects of the Divorce Settlement } \\
\hline Father owed alimony at final judgment ( 1 if yes) & .14 & $(.34)$ & .13 & $(.34)$ & $\mathrm{ns}$ \\
\hline Father had house (1 if yes) & .15 & $(.35)$ & .15 & $(.35)$ & ns \\
\hline Father had retroactive order (1 if yes) & .15 & $(.35)$ & .09 & $(.28)$ & $\mathrm{ns}$ \\
\hline Year between petition date and interview date & 2.41 & $(.58)$ & 2.15 & $(.61)$ & $*$ \\
\hline Joint legal custody ( 1 if yes) & .39 & $(.49)$ & .34 & $(.48)$ & $\mathrm{ns}$ \\
\hline Child support is percentage expressed ( 1 if yes) & .29 & $(.46)$ & .43 & $(.50)$ & * \\
\hline Number of cases & \multicolumn{2}{|c|}{103} & \multicolumn{2}{|c|}{289} & \\
\hline
\end{tabular}

Source: Wisconsin Court Record Cohorts 7 and 8, 1989-1991. Parent Survey 2.

Notes: Standard deviations are in parentheses. Calculation of mean difference is based on 103 fathers with withholding less than 548 days and 289 fathers with withholding equal to or greater than 548 days.

${ }^{*} \mathrm{p}<.05$ (two-tailed test)

${ }^{\text {a }}$ Child support compliance is the ratio of the total amount of child support paid to the amount of support owed. The ratio is top-coded to 1.2 . 


\section{FIGURE 1}

Percentage of Fathers in Five Compliance Ranges by Perceptions of Fairness and Use of Routine Income Withholding

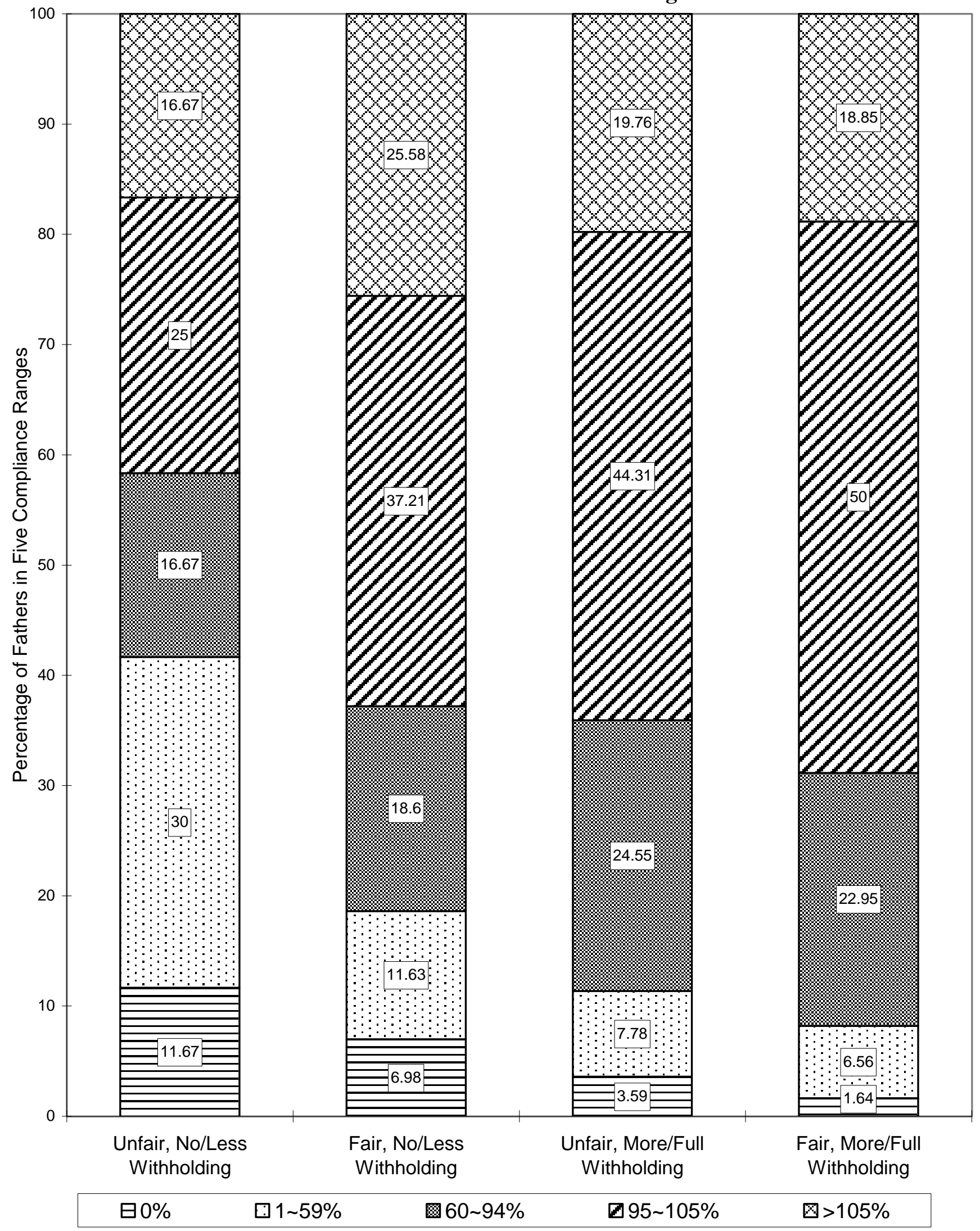


paying zero, paying anything less than 60 percent of what they owed, paying 60 percent up to 95 percent of what they owed, paying 95 percent to 105 percent of what they owed, and paying more than 105 percent of what they owed. The figure shows that noncompliance or partial compliance ( 0 percent to 95 percent) is the likely outcome among fathers who think their child support orders are "unfair" and who have no or limited withholding. In contrast, complete compliance (95 percent to 105 percent) is the likely outcome among fathers who think their child support orders are "fair" and who have more or full withholding. Of the fathers who think their child support orders are "fair" and have no or limited withholding, 26 percent pay more than what they owe, a higher percentage than in the other three groups of fathers.

\section{Other Control Variables}

Other variables are controlled in the analysis because they have been shown to affect nonresident fathers' compliance with their child support orders. These variables can be grouped into two categories: "parents' resources and families' characteristics" and "aspects of the divorce settlement."

Parents' resources and families' characteristics include nonresident fathers' income, fathers' self-employment, resident mothers' income, and mothers' reliance on AFDC. Other researchers have shown that higher incomes increase nonresident fathers' child support payments (Seltzer 1991;

Teachman 1991; Hill 1992; Peters et al. 1993) and compliance (Meyer and Bartfeld 1996). But the effect of resident mothers' income on nonresident fathers' compliance behavior is unclear. For example, Sonenstein and Calhoun (1990), and Seltzer (1991) found that a higher income for resident mothers was linked to lower compliance, but Teachman (1991), Hill (1992), Meyer and Bartfeld (1996) found that a higher income for resident mothers is unrelated to nonresident fathers' compliance.

Moreover, Garfinkel and Oellerich (1989) and Edin (1995: 217) found that nonresident fathers' compliance is lower when their ex-spouses are on AFDC because these fathers usually do not have regular employment and thus earn less than fathers without welfare-reliant children. Furthermore, the 
welfare system provides little incentive for fathers to pay child support because, at the time of this study, the Office of Child Support Enforcement agencies kept all but $\$ 50$ of a father's payment, and thus mothers and their children could not know how much these fathers actually paid, even if these fathers fully complied with their child support obligations. But Meyer and Bartfeld (1996) did not find a significant relationship between mothers' AFDC participation and fathers' child support compliance.

In addition, remarriage of either parent and cohabitation status are included in the model. Sonenstein and Calhoun (1990) found that remarried fathers have a higher compliance rate than fathers who remain single. But Teachman (1991), Hill (1992), Peters et al. (1993), and Meyer and Bartfeld (1996) found that remarried fathers have the same compliance rates as fathers who do not remarry. Hill (1984) suggested that men who remarry have stronger feelings about family and that this carries over into child support payment patterns. Alternatively, remarriages may be an indication of the lifetime earnings of nonresident parents. That is, nonresident parents who can afford to support additional families may be more likely to remarry. The remarriage of resident mothers also has inconsistent effects on nonresident fathers' child support payment behavior. For instance, O’Neill (1985), Sonenstein and Calhoun (1990), and Hill (1992) found that remarriage of resident mothers reduces fathers' child support payments. However, Peters et al. (1993), Teachman (1991), and Meyer and Bartfeld (1996) did not find any effect of mothers' remarriage in their analysis.

Finally, the number and the age of minor children are also included in the model. Beller and Graham (1986, 1991) and Teachman (1991) found that the greater the number of children, the more child support is made, controlling for the amount of child support orders. Moreover, Beller and Graham (1986) found that the presence of older children increases nonresident fathers' child support payments. This may occur because fathers have a longer relationship or a greater investment in older children than in younger children. However, the effect of the number of children is not found by Peters et al. (1993) and Meyer 
and Bartfeld (1996), and the effect of the age of children is not found by Teachman (1991) and Meyer and Bartfeld (1996).

Aspects of the divorce settlement include five variables that may affect nonresident fathers' child support payments: whether fathers owed alimony, whether fathers owned the house after divorce, whether fathers had retroactive orders, the length of time between petition date and interview date, and whether fathers shared joint legal custody. Whether fathers owed alimony and whether they had ownership of their houses may be indications of the fathers' wealth. A child support order may be less burdensome for a richer father than a poor father. Moreover, fathers who had retroactive support orders are likely to be those fathers who owe past-due support. As a result, these fathers' compliant behavior may be less regular than those who did not have retroactive orders.

In addition, the length of the time between separation and the time of interview is controlled in the model. Some studies have suggested that nonresident fathers' motivations to pay support may be confounded with the time since divorce. For example, Teachman (1991) and Garfinkel and Robins (1994) found that compliance is higher among fathers who have been divorced for a shorter time when attachment to children is still strong. However, Peters et al. (1993) found that time since divorce is not a statistically significant influence on compliant behavior.

Finally, whether fathers shared legal custody with mothers may indicate how attached fathers are to their children and thus affect fathers' compliance with their child support obligations. Some studies have suggested that nonresident fathers who share joint legal custody with their ex-wives have higher compliance or make higher payments than fathers who do not (Arditti, 1991). However, this hypothesis is not supported by other studies. For instance, Peters et al. (1993), Seltzer (1991), Sonenstein and Calhoun (1990), and Meyer and Bartfeld (1996) found that joint legal custody does not lead to high compliance or high payments. 


\section{PREDICTION OF CHILD SUPPORT COMPLIANCE}

The purpose of this analysis is to test two competing hypotheses, one suggesting that the perceptions of fairness and the use of income withholding have independent effects on child support compliance, and the other suggesting an interaction effect, i.e., the effect of routine income withholding depends on whether fathers perceive their support orders as fair or not. For this analysis, the compliance ratio is top-coded to 1.2 because the proportion of fathers in the categories where the compliance ratio range is over 1.2 is less than 5 percent (see Table 1). Most previous child support researchers top-coded the compliance ratio to 1 (e.g., Garfinkel and Klawitter 1990; Meyer and Bartfeld 1996) because it is conceptually easy to think of those fathers as being "fully compliant." However, doing so will take away an important variation in the variable. Top-coding the compliance ratio to 1.2 in this analysis also reduces variation for 6.6 percent of the cases, but this is better than losing variation for 35.7 percent of the cases when top-coding this variable to 1 .

Because the distribution of the compliance ratio is truncated at 0 and 1.2, two-limited tobit regression is used for the multivariate analysis (Maddala 1983: 160-162). The model is expressed as follows:

$$
\begin{array}{rlrl}
y_{i}^{*}= & \beta^{\prime} \boldsymbol{x}_{i}+\epsilon_{i} \\
y_{i} & =0 & & \text { if } y_{i} \leq 0 \\
& =y_{i}{ }^{*} & & \text { if } 0<y_{i}<1.2 \\
& =1.2 & & \text { if } y_{i} \geq 1.2
\end{array}
$$

Where $y_{i}{ }^{*}$ is the latent variable, $y_{i}$ is the observed dependent variable (compliance ratio), and 0 and 1.2 are the lower and upper limits.

Table 3 shows the results of estimating two separate tobit regressions, one without the interaction between perceived fairness and the use of income withholding and the other with the interaction. Parents' resources and families' characteristics and aspects of divorce settlement that may affect the estimate of 
TABLE 3

Two-sided Tobit Parameters from Regression of Child Support Compliance over the 24-Month Period on Selected Independent Variables and Mean of Each Independent Variable ( $\mathbf{N}=392)$

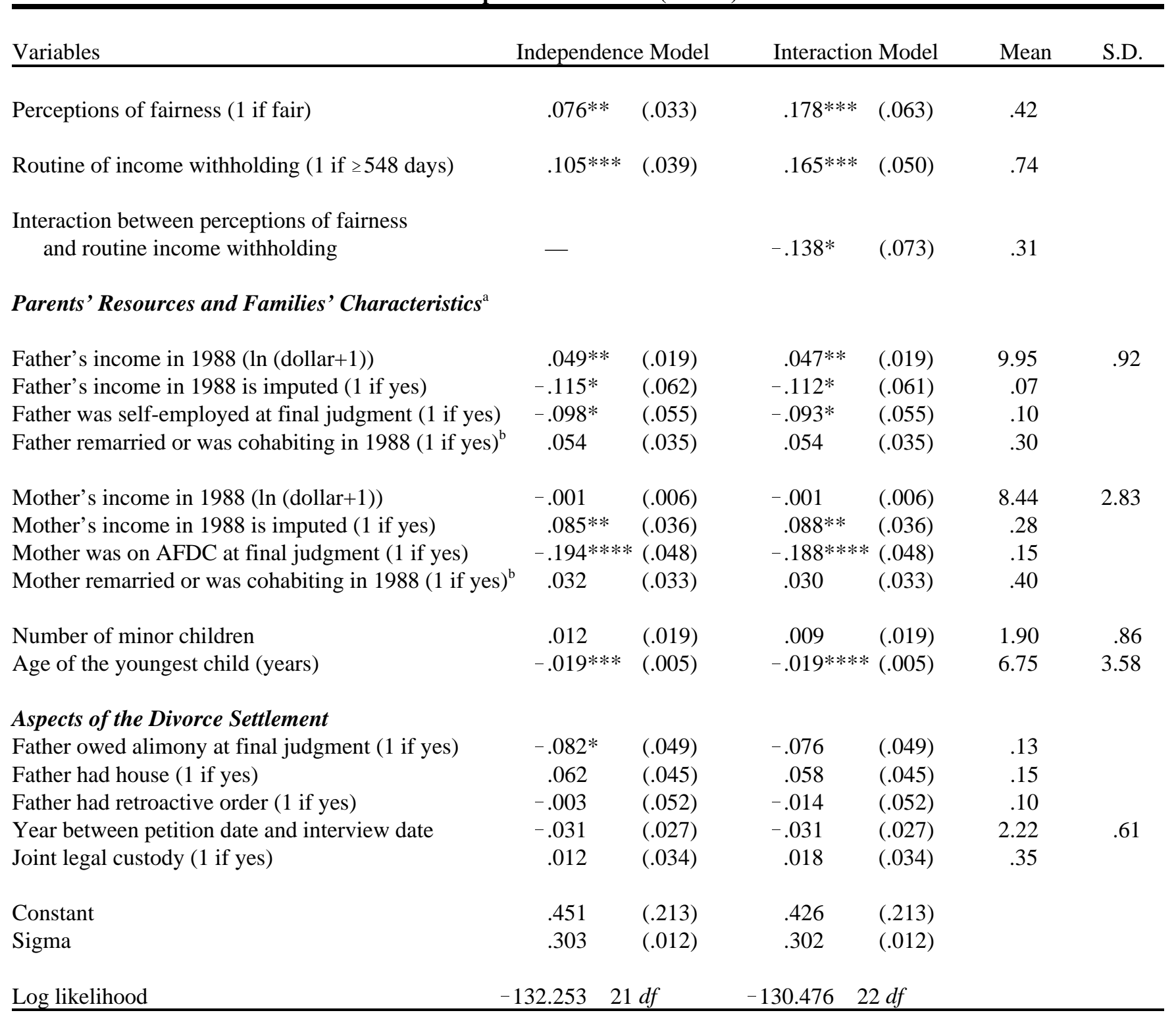

Source: Wisconsin Court Record Cohorts 7 and 8. Parent Survey 2.

Notes: Standard errors are in parentheses. The dependent variable is the ratio of the total amount of child support paid to the amount of support owed over the 24-month period. The ratio is top-coded to 1.2. See text for discussion. This model also includes four dummy variables to control for different sources of income information (DOR, DILHR, CRD, and PS2).

$* \mathrm{p}<.10,{ }^{* *} \mathrm{p}<.05, * * * \mathrm{p}<.01, * * * \mathrm{p}<.001$ (two-tailed test)

${ }^{a}$ Except for variables about whether fathers were self-employed and whether mothers were on AFDC, the reports of parents' resources and family characteristics are based on fathers' reports in the PS2. If fathers' reports of their or their ex-spouse's incomes are missing, information from the court records is substituted. Two dummy variables indicating such a substitution are included in the model.

${ }^{b}$ Whether parents remarried and whether parents were cohabiting were tested separately and neither was significant. 
the child support compliance ratio are included in the model. ${ }^{10}$ The numbers in the cells of the second and third columns are tobit coefficients, and standard errors are in parentheses. The numbers in the cells of the last two columns are the means and standard deviations, respectively, of the independent variables.

The results of the independence model in Table 3 show that, controlling for other independent variables included in the model, fathers' perceived fairness of their child support orders increases their subsequent compliance with the orders. Income withholding also has a positive effect on fathers' compliance with their child support obligations. The results suggest that strategies under the compliancebased approach and the consensus-based approach are important in increasing fathers' child support compliance. In the category of parents' resources and families' characteristics, the variable of fathers' income has a positive effect on their subsequent compliance, but fathers who are self-employed have lower child support compliance than employed fathers. This is consistent with previous child support studies that have shown that compliance by fathers partly depends on their economic resources and that compliant behavior of self-employed fathers is unlikely to be enforced by withholding their incomes.

In addition, fathers are less likely to comply with their child support orders when their exspouses are AFDC recipients. Mothers' reliance on AFDC is measured at the time of final judgment (before the time of interview) and fathers' compliance is measured after the interview, so this result suggests that welfare assistance might decrease fathers' sense of responsibility for supporting their children. However, the interpretation of the causal relationship should be made with caution because it is possible that these fathers were very poor before the interview and continued their poverty after the interview. Thus, their poverty, not the mother's reliance on welfare, may be the cause of their noncompliance.

\footnotetext{
${ }^{10}$ The model also includes four dummy variables to control for different sources of income information (DOR, DILHR, CRD, and PS2). The result indicates that income information reported in the PS2 tends to be lower than income information from other sources (data not shown).
} 
Furthermore, fathers are less likely to comply with their child support orders when their youngest children get older. As children grow older, fathers may decrease their involvement with their children. The data also provide evidence that fathers who owe alimony have a lower degree of child support compliance than fathers who do not owe alimony. This may occur because fathers equate alimony with child support.

In Table 3, the interaction term (-.138) is negative and is calculated to be significant at the .06 level, which lends support to the interaction hypothesis. ${ }^{11}$ While withholding and perceptions of fairness both have positive effects on compliance, the effect of withholding is smaller when fathers perceive their support orders as fair. Stated differently, withholding matters more in the absence of fairness. To better elaborate this point, I computed predicted means of child support compliance ratio for four groups of fathers, based on routine income withholding and perceptions of fairness. ${ }^{12}$ The predicted mean of compliance ratio is lowest among fathers who perceive their support orders as unfair and when routine income withholding is not used (.66). For other fathers who also perceive their support orders as unfair, the use of routine income withholding substantially increases their compliance by 22 percent (.88-.66). In contrast, when fathers think their support orders are fair, their compliance is high and the use of routine income withholding does not substantially improve their compliance (6 percent, from .83 without withholding to .89 with withholding). In sum, the data provide support for the interaction hypothesis. ${ }^{13}$

\footnotetext{
${ }^{11}$ Although the coefficient reaches statistical significance at the .06 level, the effect cannot be ignored for two reasons. First, the use of different cutoff points ( 0 days, 183 days, 365 days, and 730 days) does not change the magnitudes and signs of other coefficients in the model. In general, the interaction effect of perceived fairness and withholding becomes stronger as the cutoff day increases, but the model using 730 days fits the data slightly worse than the model using 548 days as the cutoff point (data not shown). Second, because the sample size is small (i.e., bigger variation among samples), coefficients are likely to be rejected at the .05 level.

${ }^{12}$ The predicted means are computed by taking into account the probability of falling at the lower bound, in the middle, and at the upper bound of the distribution. The computation is performed using Stata Release 5.0 (Stata Corp. 1997).

${ }^{13}$ I also tried using the number of days, instead of a dichotomous variable with an arbitrary cutoff point, in the multivariate model. The model generally shows results similar to those using dichotomous variables but fits the data slightly worse than the models using dichotomous variables (data not shown). To make interpretation of the interaction effect easy, I used the measure of routine income withholding in a dichotomous form.
} 
It is possible that fathers' previous compliant behavior may also affect their subsequent payments. Therefore, a measure of fathers' child support compliance in 1988, about 1 year before the 24month period, is included in the model (data not shown). The results do not change the relationships of other independent variables to the compliance ratio. In particular, the magnitude and sign of the significance of the interaction effect of fairness and withholding remain unchanged. Moreover, fathers' previous compliant behavior increases their subsequent compliance with support orders. ${ }^{14}$

\section{SUMMARY AND DISCUSSION}

This paper uses the perceptions of nonresident fathers about the fairness of their child support orders and an independent measure of their subsequent compliance with child support obligations over a 24-month period to examine two competing hypotheses. One suggests that routine income withholding has an effect on fathers' compliant behavior, regardless of the perceived fairness of their support orders (independent hypothesis); the other suggests that routine income withholding has a greater effect on compliance when fathers think their child support orders are unfair than when they think the orders are fair (interaction hypothesis). The results support the interaction hypothesis, that is, the use of routine income withholding substantially increases fathers' compliant behavior in the absence of perceived fairness (from .66 to .88).

The result of this study seems to confirm the claim of some fathers' rights groups that if child support orders were fair, fathers would pay more. However, little research has been conducted to understand how to improve nonresident fathers' perceptions of the fairness of their child support orders.

\footnotetext{
${ }^{14}$ However, including fathers' previous compliant behavior may cause an autocorrelation problem (Neter, Wasserman, and Kutner 1989: 484). That is, the error term of the dependent variable and that of the lagged independent variable (previous compliant behavior) are positively correlated.
} 
Nevertheless, based on the consensus-based approach, two types of strategies may be helpful for improving nonresident fathers' compliance with child support obligations.

One type of strategy is to revise child support guidelines so that support orders are likely to be perceived as "fair" by nonresident fathers. A child support order that is perceived as "fair" by nonresident fathers, however, may be too low to meet their children's needs. In a comparison of 312 former couples who were divorced in Wisconsin between 1986 and 1988, Lin (1997) found that the average monthly amount of child support considered "fair" by resident mothers is $\$ 501$, which is about the same as the amount calculated using the Wisconsin child support guideline (\$512) for these families. However, the average monthly amount of child support considered "fair" by nonresident fathers is $\$ 290$, about 40 percent less $([\$ 501-\$ 290]$ / \$501) than the average amount of mothers' estimates. Thus, revising child support guidelines according to what is a "fair" child support order from the perspective of nonresident fathers may reduce children's well-being.

The second type of strategy is to standardize child support obligations and to reduce deviations of child support from the standard. If nonresident fathers come to believe that other fathers are taking child support as seriously as they take social security and income tax payments, they may view their own child support obligations as fair and therefore be more willing to comply with their support orders.

The two types of strategies do not necessarily conflict with each other. As the U.S. child support system becomes more rationalized to the level of the current income tax and social security systems, consensus on child support obligations may be reached by setting more equitable (but adequate) child support orders that apply uniformly to all affected parents. Policymakers' decisions about what strategies to pursue for ensuring nonresident parents' compliance with their child support will depend heavily on additional empirical studies of how parents perceive the fairness of their child support arrangements. 


\section{References}

Andenaes, J. 1971. "The Moral or Educative Influence of Criminal Law.” Journal of Social Issues 27(2): $17-31$.

Arditti, Joyce A. 1991. "Child Support Noncompliance and Divorced Fathers: Rethinking the Role of Paternal Involvement." Journal of Divorce and Remarriage 14: 107-119.

Arendell, Terry. 1995. Fathers \& Divorce. Thousand Oaks, California: SAGE Publications.

Argys, Laura Mesple. 1993. "The Determination of Child Support Awards and the Strategic Use of Transfers and Child Expenditures: A Theoretical and Empirical Investigation." Ph.D. dissertation, Department of Economics, University of Colorado.

Bartfeld, Judi. 1997. Post-Divorce Economic Inequality between Women and Men: An Assessment of the Roles of Children and Child Support. Ph.D. dissertation, School of Social Work, University of Wisconsin-Madison.

Beller, Andrea H., and John W. Graham. 1986. "The Determinants of Child Support Income.” Social Science Quarterly 67: 353-364.

Beller, Andrea H., and John W. Graham. 1991. "The Effect of Child Support Enforcement on Child Support Payments." Population Research and Policy Review 10: 91-116.

Blake, Judith, and Kingsley Davis. 1964. "Norms, Values, and Sanctions." Chapter 13 in Handbook of Modern Sociology, edited by R. Faris. Chicago: Rand McNally.

Burmeister, Sonny H. W. 1991. "Noncompliance Is the Symptom, Fairness the Problem” Today's Dads, Vol. 4, No. 6, Madison, Wisconsin: Wisconsin Fathers for Equal Justice, Inc.

Chambers, David. 1979. Making Fathers Pay: The Enforcement of Child Support. Chicago: University of Chicago Press.

Danziger, Sheldon H. and Daniel H. Weinberg. 1994. "The Historical Record: Trends in Family Income, Inequality, and Poverty." Chapter 2 in Confronting Poverty: Prescriptions for Change, edited by Sheldon H. Danziger, Gray D. Sandefur, Daniel H. Weinberg. Cambridge, MA: Harvard University Press.

Depner, Charlene E., Karen Cannata, and Isolina Ricci. 1994. "Client Evaluations of Medication Services: The Impact of Case Characteristics and Mediation Service Models." Family and Conciliation Courts Review 32: 306-325.

Duncan, Greg, and Saul Hoffman. 1985. "A Re-consideration of the Economic Consequences of Marital Dissolution." Demography 22: 485-497.

Edin, Kathryn. 1995. "Single Mothers and Child Support: The Possibilities and Limits of Child Support Policy." Children and Youth Services Review 17: 203-230. 
Garfinkel, Irwin, and Donald Oellerich. 1989. "Noncustodial Fathers' Ability to Pay Child Support." Demography 26: 219-233.

Garfinkel, Irwin, and Marieka M. Klawitter. 1990. "The Effect of Routine Income Withholding of Child Support Collections.” Journal of Policy Analysis and Management 9: 155-177.

Garfinkel, Irwin, and Philip K. Robins. 1994. "The Relationship between Child Support Enforcement Tools and Child Support Outcomes." Chapter 5 in Child Support and Child Well-Being, edited by Irwin Garfinkel, Sara S. McLanahan, and Philip K. Robins. Washington, D.C.: The Urban Institute Press.

Garfinkel, Irwin, Sara S. McLanahan, and Philip K. Robins. 1994. "Child Support and Child Well-Being: What Have We Learned?" Chapter 1 in Child Support and Child Well-Being, edited by Irwin Garfinkel, Sara S. McLanahan, and Philip K. Robins. Washington, D.C.: The Urban Institute Press.

Garfinkel, Irwin, Cynthia Miller, Sara S. McLanahan, and Thomas L. Hanson. 1996. "Deadbeat Dads or Inept States? A Comparison of Child Support Enforcement Systems.” Unpublished manuscript.

Garfinkel, Irwin, Sara S. McLanahan, Judith A. Seltzer, and Daniel R. Meyer. "The Effects of Child Support Policy on Nonresident Fathers: Overview and Summary." Forthcoming in Child Support Enforcement and Nonresident Fathers, edited by Irwin Garfinkel, Sara S. McLanahan, Judith A. Seltzer, and Daniel R. Meyer. New York: Russell Sage Foundation.

Gibbs, Jack P. 1975. Crime, Punishment, and Deterrence. New York: Elsevier.

Gordon, Anne R. 1994. "Implementation of the Income Withholding and Medical Support Provisions of the 1984 Child Support Enforcement Amendments" Chapter 3 in Child Support and Child WellBeing, edited by Irwin Garfinkel, Sara S. McLanahan, and Philip K. Robins. Washington, D.C.: The Urban Institute Press.

Grasmick, Harold G., and Donald E. Green. 1980. "Legal Punishment, Social Disapproval, and Internalization as Inhibitors of Illegal Behavior." The Journal of Criminal Law \& Criminology 71: 325-335.

Grasmick, Harold G., and Donald E. Green. 1981. "Deterrence and the Morally Committed." Sociological Quarterly 22: 1-14.

Greif, Geoffrey L. 1985. Single Fathers. Lexington, MA: Lexington Books.

Harrington, Bill. 1996. "Minority Report and Policy Recommendations to the United States Commission on Child and Family Welfare: Final Report and Recommendations to the Present and Congress of the United States." Unpublished memo. American Fathers Alliance.

Hill, Martha S. 1984. "PSID Analysis of Matched Pairs of Ex-Spouses: The Relation of Economic Resources and New Family Obligations to Child Support Payments." Unpublished manuscript. Survey Research Center, Institute for Social Research, University of Michigan, Ann Arbor. 
Hill, Martha S. 1992. "The Role of Economic Resources and Remarriage in Financial Assistance for Children of Divorce." Journal of Family Issues 13: 158-178.

Horwitz, Allan V. 1990. The Logic of Social Control. New York: Plenum Press.

Lempert, Richard. 1981-1982. "Organizing for Deterrence: Lessons from a Study of Child Support." Law \& Society Review 16: 513-568.

Lin, I-Fen. 1997. Perceptions of Fairness and Compliance with Child Support Obligations. Ph.D. dissertation, Department of Sociology, University of Wisconsin-Madison.

Lin, I-Fen, Nora Cate Schaeffer, and Judith A. Seltzer. 1997. "Causes and Effects of Nonparticipation in a Child Support Study." Unpublished manuscript.

Maccoby, Eleanor E., and Robert H. Mnookin. 1992. Dividing the Child: Social and Legal Dilemmas of Custody. Cambridge, MA: Harvard University Press.

Maddala, G. S. 1983. Limited-Dependent and Qualitative Variables in Econometrics. New York: Cambridge University Press.

Meyer, Daniel R., and Judi Bartfeld. 1992. "The Effects of the Immediate Withholding of Child Support on Collections Over Time." Report submitted to Wisconsin Department of Health and Social Services. Institute for Research on Poverty, University of Wisconsin-Madison.

Meyer, Daniel R., and Judi Bartfeld. 1996. "Compliance with Child Support Orders in Divorce Cases." Journal of Marriage and the Family 58: 201-212.

Meyer, Daniel R., Judi Bartfeld, Irwin Garfinkel, and Patricia Brown. 1996. "Child Support Reform: Lessons from Wisconsin.” Family Relations 45: 11-18.

Mnookin, Robert H. and Lewis Kornhauser. 1979. "Bargaining in the Shadow of the Law: The Case of Divorce.” Yale Law Journal 88: 950-997.

Neter, John, William Wasserman, and Michael H. Kutner. 1989. Applied Linear Regression Models. 2nd edition. Homewood, IL: Irwin.

Nuta, Virginia Rhodes. 1986. "Emotional Aspects of Child Support Enforcement." Family Relations 35: 177-181.

O’Neill, June. 1985. “Determinants of Child Support.” Unpublished manuscript. Washington, D.C.: The Urban Institute.

Pearson, Jessica, and Nancy Thoennes. 1985. "Mediation Versus the Courts in Child Custody Cases." Negotiation Journal 235-244.

Personal Responsibility and Work Opportunity Reconciliation Act of 1996. Public Law No. 104-193, 110 Stat. 2105. 
Peters, H. Elizabeth, Laura M. Argys, Eleanor E. Maccoby, and Robert H. Mnookin. 1993. "Enforcing Divorce Settlements: Evidence from Child Support Compliance and Award Modifications." Demography 30: 719-735.

Peterson, Richard R. 1996. "A Re-evaluation of the Economic Consequences of Divorce." American Sociological Review 61: 528-536.

Reiss, Alberg J., Jr. 1984. "Selecting Strategies of Social Control Over Organizational Life." Chapter 2 in Enforcing Regulation, eds. Keith Hawkins and John M. Thomas. Boston: Kluwer-Nijhoff.

Rubin, Richard M., Mary Utne O’Brien, and Seymour Sudman. 1988. "The Survey of Absent Parents (SOAP): Report of the Methodology of A Pilot Study.” NORC, University of Chicago.

Schaeffer, Nora Cate, Judith A. Seltzer, and Marieka Klawitter. 1991. "Estimating Nonresponse and Response Bias: Resident and Nonresident Parents' Report About Child Support.” Sociological Methods and Research 20: 30-59.

Seltzer, Judith A. 1991. "Legal Custody Arrangements and Children's Economic Welfare." American Journal of Sociology 96: 895-929.

Silberman, M. 1976. "Toward A Theory of Criminal Deterrence." American Sociological Review 41: $442-461$.

Sonenstein, Freya L., and Charles A. Calhoun. 1990. "Determinants of Child Support: A Pilot Survey of Absent Parents." Contemporary Policy Issues 8: 75-94.

Sorensen, Elaine. 1995. "A National Profile of Noncustodial Fathers and Their Ability to Pay Child Support.” Unpublished manuscript. Washington, D.C.: The Urban Institute.

Stafford, Mark C., and Mark Warr. 1993. "A Reconceptualization of General and Specific Deterrence." Journal of Research in Crime and Delinquency 30: 123-135.

Stata Corp. 1997. Stata Statistical Software: Release 5.0. College Station, TX: Stata Corporation.

Teachman, Jay D. 1991. "Who Pays? Receipt of Child Support in the United States." Journal of Marriage and the Family 53: 759-772.

Thibaut, John, and Harold. H. Kelley. 1959. The Social Psychology of Groups. New York: Wiley.

Thibaut, John, Nehemia Friedland, and Laurens Walker. 1974. "Compliance with Rules: Some Social Determinants.” Journal of Personality and Social Psychology 30: 792-801.

Tittle, Charles R. 1977. "Sanction Fear and the Maintenance of Social Order." Social Forces 55: 579-596.

Toby, Jackson. 1964. "Is Punishment Necessary?" Journal of Criminal Law, Criminology, and Police Science 55: 332-337. 
U.S. Bureau of the Census. 1996. Statistical Abstract of the United States: 1996 (116th edition). Washington, D.C.

U.S. Bureau of the Census. 1995. Child Support for Custodial Mothers and Fathers: 1991. Current Population Reports, Series P60-187. Washington, D.C.: U.S. Government Printing Office.

U.S. Bureau of the Census. 1991. Child Support and Alimony: 1989. Current Population Reports, Series P60-173. Washington, D.C.: U.S. Government Printing Office.

U.S. House of Representatives Committee on Ways and Means. 1996. 1996 Green Book: Background Material and Data on Programs within the Jurisdiction of the Committee on Ways and Means. Washington, D.C.: U.S. Government Printing Office.

Ventura, Stephanie J., Joyce A. Martin, Sally C. Curtin, and T. J. Mathews. 1997. Report of final natality statistics, 1995. Monthly Vital Statistics Report; vol 45 no 11, supp 2. Hyattsville, MD: National Center for Health Statistics.

Weitzman, Lenore J. 1985. The Divorce Revolution: The Unexpected Social and Economic Consequences for Women and Children in America. New York: The Free Press.

Wiseman, Michael. 1996. "Welfare Reform in the United States: A Background Paper." Housing Policy Debate 7: 595-648.

Zimring, Frank. 1971. "Perspectives on Deterrence.” Public Health Service Publication No. 2056.

Washington, D.C.: U.S. Government Printing Office. 